\title{
Peridot: Types of Deposits and Formation Conditions
}

\author{
S. Sokolov $(\bowtie)$ \\ FSBE “All-Russian Institute of Mineral Raw Materials” (VIMS), \\ Moscow, Russia \\ vims-sokol@mail.ru
}

\begin{abstract}
The generalized information about the peridot from deposits and ore occurrence of well-known formation type is presented in this paper. Peridots from specific deposits vary in the accompanying mineral associations. These gems, depending on the genesis, contain differing in phase composition inclusions of mineral-forming medium and have different crystallization temperatures.
\end{abstract}

Keywords: Peridot $\cdot$ Formations $\cdot$ Deposits $\cdot$ Origin $\cdot$ Temperature of formation

\section{Introduction}

The increased interest to peridot - jewelry varieties of olivine, was observed over the last years. This has resulted in numerous publications on the geology, mineralogy, and genesis of this gem. Peridot has been found in almost 30 countries and on all continents, including Antarctica (gem-quality mineral is present in the basalts from the Ross Island); furthermore it was diagnosed in several stony-iron meteorites. Peridot is present in different geological formations, which almost all (with the exception of exogenous placers) belong to derivatives of endogenous processes and often genetically related to ultrabasic and basic rocks.

\section{Formation Types of the Deposits of Peridot}

Diamond-bearing kimberlites, concentrating peridot in different quantities, are known in Yakutia (Udachnaya-Vostochnaya and Mir pipes), the Republic of South Africa (Kimberly and De Beers pipes), and in Tanzania (Mvadun pipe).

Ultrabasic-alkaline rocks and carbonatites - UAC complexes. Peridot installed at complexes of the Kola peninsula (Kovdor) and Polar Siberia (Kugda).

Basalts and basaltoids (normal and (sub) alkaline). Peridot phenocrysts in the nodules of peridotites and olivenites are situated in lava flows and volcanic craters at deposits and ore occurrence in Russia, USA, Hawaiian Island, the Czech Republic, Madagascar Island, Ethiopia, China, Pakistan, Australia, Antarctica.

Alpinotype hyperbasites. The most famous deposit of peridot - Zabargad Island is classed to this formation type. They are known also in Russia at the East Sayan and at the South Urals. 
Placer deposits. Eluvial-deluvial plasers are the most productive among the exogenous deposits of peridot. They are connected with different genetic types of primary deposits of this gem (Zabargad, San-Carlos, Kugda).

\section{Origin and Formation Conditions of Peridot}

Peridots from the deposits of different formation clearly differ in the associations of accompanying minerals.

A detailed study of the jewelry peridots from the Kovdor and Kugda deposits allowed us to determine the specific features of their micromineralogy, (Yarmishko and Sokolov 2005): crystalline inclusions, represented mainly by minerals accompanying to peridot; decomposition products (magnetite dendrites and magnetite-diopside plates; crystallized melt inclusions.

Fixation multiphase crystallized melt inclusions in peridots confirms the magmatic nature of the deposits some formation types. For example, olivine and calcite from kimberlites of the Udachnaya-Vostochnaya pipe contain the melt inclusions the total temperature range of homogenization of which is $1100-880{ }^{\circ} \mathrm{C}$ (Tomilenko et al. 2009). Peridots from basalts of the Hawaiian Islands contain the inclusion of glass (Gubelin and Koivula 1992). The melt inclusions in jewelry peridot from the Kovdor deposits were homogenized at temperatures of $970-930{ }^{\circ} \mathrm{C}$. Crystallization of peridot at the Zabargad deposit occured in temperature range from 900 to $750{ }^{\circ} \mathrm{C}$ (Maaskant 1986).

\section{References}

Gübelin EJ, Koivula JI (1992) Photoatlas of inclusions in gemstones. ABC Edition, Zurich Maaskant P (1986) Electron probe microanalyses of unopened fluid inclusions, semiquantitative approach. Neues Jahrb Miner 7:297-304

Tomilenko AA, Kovyazin SV, Dunlyansky YuV, Pokhilenko LN (2009) Primary melt and fluid inclusions in minerals from kimberlites of the Udachnaya-Vostochnaya pipe, Yakutia. ECROFI-XX. Abstracts, University of Granada, pp 255-256

Yarmishko SA, Sokolov SV (2005) Micromineralogy of peridots from rocks of alkalineultrabasic massifs. In: VII International Conference «New Ideas in Earth Sciences». Abstracts, vol 2, Moscow, p 76. (in Russian)

Open Access This chapter is licensed under the terms of the Creative Commons Attribution 4.0 International License (http://creativecommons.org/licenses/by/4.0/), which permits use, sharing, adaptation, distribution and reproduction in any medium or format, as long as you give appropriate credit to the original author(s) and the source, provide a link to the Creative Commons license and indicate if changes were made.

The images or other third party material in this chapter are included in the chapter's Creative Commons license, unless indicated otherwise in a credit line to the material. If material is not included in the chapter's Creative Commons license and your intended use is not permitted by statutory regulation or exceeds the permitted use, you will need to obtain permission directly from the copyright holder. 